\title{
SCIENCE.-Supplement.
}

FRIDAY, MARCH $26,1886$.

\section{EDUCATIONAL TENDENCIES IN JAPAN AND IN AMERICA.}

IT has for some time past been a cause of wonder that the bureau of education has been able to do so much and so good work with the limited means at its disposal, and receiving but slight recognition from the other governmental departments. Two recent circulars of this bureau will, by their great interest and value, serve to increase this wonder.

One of them deals with education in Japan. ${ }^{1}$ The population of the empire in 1882 was $37,041,-$ 368 , and the school population, comprising all children between the ages of six and fourteen, made up 5,750,946 of this number.

Education is given more official consideration in Japan than here, for it constitutes one of the ten departments of the privy council, and has a minister allotted specially to it. The school organization follows closely the division of the empire for administrative purposes into nine circuits and eighty-four provinces. A school committee is organized in each minor civil division, ward or village; and it conducts all business relating to school attendance, the establishment and maintenance of schools, etc., within its jurisdiction. The tenure of such a committee is not less than four years, and it is composed of men selected by the governor of the province, from a list nominated to him by the citizens of the school district. A committeeman must be over twenty years of age, a property-holder, and a bona fide resident of the district from which he is nominated. The directors, librarians, professors, and teachers are appointed and dismissed in various ways, according to the importance of their office. Some are appointed and dismissed by the emperor himself, others by the prime minister on the recommendation of the minister of education, others by the minister of education himself. Their salaries range from 4,800 yen (one yen is equivalent to 85.8 cents) in the case of a rector or a professor of highest grade, to 540 yen or less in the case of an ordinary teacher.

Education has been under government super-

1 Circulars of information of the bureau of education. No. 4, 1885. Education in Japan. Washington, Government, 1885. $8^{\circ}$. vision in Japan since 270 A.D., but it was in the years from 1868 to 1871 , following the political reform of the country, that it was placed on its present footing. The present educational code only dates from 1880 . The school system comprises kindergarten, elementary schools, middle schools, and a university at Tokio. There are also female schools, commercial and industrial schools, and normal schools for the training of teachers. Nineteen libraries and four museums of high rank are under the control of the department. Students are frequently sent abroad to complete courses of study, fifty having been so sent since 1875 . Twenty-two such students are abroad at present, seventeen of whom are in Germany. The school funds are raised as part of the national taxes, and the lands occupied by schools are usually government lands: when they do not belong to the government, they are exempt from taxation. In 1881 the educational expenses of the empire amounted to $6,591,878.123$ yen, - about 36 per cent of the total expenditure. 8.8 per cent of the entire population were under instruction in 1883 in 30,156 elementary schools, engaging the services of 24,605 teachers, 1,878 assistant teachers, and 64,017 pupil teachers.

The second of the reports to which we have referred is no less replete with information than the former, but from its character it contains more that is suggestive. It was drawn up by the late Charles O. Thompson, Ph.D., of Terre Haute, Ind., and is an essay on technical instruction in Europe. ${ }^{1}$

Into the details of this report space forbids us to enter, but it is a valuable compendium of the system and methods of technical instruction in the various countries of Europe. America is by no means deficient in recognizing the importance of technical schools; but we need to learn all we can on this subject, and call to our aid, when attainable, the experience of other countries, for technical education bids fair to be the education of the future. In our development of free education we have tended to overestimate the dignity of the professions and to underestimate the dignity of the trades. From Germany comes the cry that there are too many educated men, and not enough places for them; and in our large cities we see

1 Circulars of information of the bureau of education. No. 3, 1885. A review of the reports of the British royal commissioners on technical instruction, with notes, by the late Charles $O$. Thompson. Washington, Government, 1885. $8^{\circ}$. 
hundreds more lawyers and doctors than can obtain a decent living.

The remedy for all this must lie largely in technical education. Teach a trade and the practical application of principles, and inculcate the lesson that no calling is dignified in itself, but it becomes what those who follow it choose to make it. We believe that Professor Thompson's essay is a positive contribution to our knowledge of this subject, and therefore should be carefully studied by all who are interested in education.

Nicholas MURRAY BUTLER.

\section{THE CHARACTERS OF CHILDREN AS EVI- DENCED BY THEIR POWERS OF OBSER- VATION.}

THE study of the powers of observation in children has been seldom attempted in a systematic way; and yet, with the tendencies and aims of modern education, there can scarcely be any subject from which might be expected more fruitful results. Professor Farlow, in his recent address before the Society of naturalists, has asserted that the schools, in the last six or seven years, have made no perceptible progress in developing these powers, and that, so far as elementary training is concerned, we are about where we were ten years ago. Furthermore, in his own experience, he finds that the tendency of education, in the lower schools at least, is to impair, rather than to sharpen, the natural powers in this respect. Considering how important an element of successful work, in most careers, this faculty is, one cannot fail to appreciate the value of experiments that may throw light upon remediable mental defects, or upon mental excellences, in childhood.

At the suggestion of Mr. Francis Galton, Mrs. Sophia Bryant, D.Sc., has recently ${ }^{1}$ attempted a series of such experiments, the results of which, though subject to fallacies, will point out a fruitful line of investigation.

Her method was the analysis of the characteristics evinced in the description of given objects by a number of school-children, all of whom were of the same age (thirteen years), and unknown to her. For this purpose they were allowed to remain for about ten minutes in a room which they did not know, and were then required to write a description of it. The one first described was a schoolroom, having certain features in common with other schoolrooms familiar to the children, but having certain others peculiar to itself, and a sufficient amount of ornament, in pic-

1 Journ. anthropol. inst. of Great Britain and Ireland, xv. 338, February, 1866. tures and otherwise, to redeem it from being quite prosaic. The results of her analyses were afterwards compared with the characteristics as given by the children's teachers; from which comparisons, in many cases, striking agreements were found. Of course, in such experiments, as the author rightly says, only repeated and varied trials can eliminate the chances of error; and much less weight should be attached to negative than to positive results. The points thus brought out were as follows:-

$1^{\circ}$. In the perception of an object a logical distinction is made between the sense-impression and the apprehension of it by the mind, as between the passive and active factors of perception. Apprehension is essentially the bringing of the new into relation with the old, and thus interpreting the new by means of the old.

In the ratio of these two factors of perception to each other, there were found signs of great variety. Impressions were sometimes numerous and faithful where the power of giving them a meaning, and thus perceiving them fully, was clearly very slight, or at least inoperative. In such cases the perception was what would be ordinarily called unintelligent. In other cases the impressions either made, or at any rate dwelt upon, were fewer, but the apprehension of them was very complete. This completeness of apprehension or understanding occasionally passed beyond the limits of full and accurate perception into pure inference. Sometimes the inference was correct, and that not by chance, since it had the marks of having been cautiously conducted. Such little phrases as ' I suppose,' or ' it is likely,' are tell-tales here, as marking off the cautious from the reckless thinker. This latter person was betrayed also by a very unmistakable hastiness of inference, which in the bad cases degenerated into actual false perception. For instance : the name 'C. W.' in the corner of a picture was reported as 'M. W.,' this being the name of a girl in school whom the young observer knew very well.

It was found, as indeed might naturally be expected, that the false perceivers were nearly always ready apprehenders, who, apparently digressing into actual inference, inferred carelessly, and projected their false inferences into false perceptions. The carelessness of such inference is of a very simple character : the impressions to the test of which the inference should be brought are there, and it is not brought to the test. This argues absence of the impulse to criticise, which is the basis of accurate habits of thought. Feebleness of the impressions is, it must be admitted, a negative cause for the false perceptions, since the test is thus kept in the background ; but it is only 